\title{
THE FLOOR OF THE ATLANTIC OCEAN
}

A DISCUSSION on "Floor of the Atlantic Occan" was held by the Royal Society on February 26, at which the session during the morning was concerned with sedimentation, and during the afternoon with the deeper structure below the layers which can be sampled. The principal contributions during the morning were made by Dr. E. C. Bullard, Prof. P. H. Kuenen, Dr. J. D. H. Wiseman, Mr. B. C. Browne, Prof. F. P. Shepard, Prof. W. B. R. King and Dr. G. M. Lees. In the afternoon the discussion was opened by Prof. M. Ewing, and he was followed by Prof. J. P. Rothé, Dr. M. N. Hill, Dr. J. L. Worzel, Prof. H. H. Hess, Dr. T. F. Gaskell and Dr. G. P. Woollard. Those in the chair were, in order, Sir Cyril Hinshelwood, Prof. W. B. R. King, Dr. E. C. Bullard, Dr. R. Stoneley and Dr. E. D. Adrian.

In his int roductory remarks, Dr. Bullard emphasized the importance of determining the methods of sedimentation in the deep sea; whether slow deposition over the whole area of the oceans, or whether cataclysmal slumping is the more important feature. He also stressed that, from the point of view of determining the climatological history of the earth from the study of the layering within a deep-sea core, it is essential to know whether in any sample the depositional sequence was exact.

Prof. P. H. Kuenen outlined the improvements in finding the characteristios of the surface layers of the deep oceans. He directed attention, in particular, to the great advances in coring methods, as shown by the largest core in the Snellius expedition of 1931 being only $2 \mathrm{~m}$. in length in comparison with the $20 \mathrm{~m}$. obtained by Kullenberg by means of his piston corer in the Albatross expedition, and longer cores than these are now being obtained. Further valuable contributions to the study of sedimentation from work at sea comes from the bottom photography which has been undertaken by Prof. M. Ewing and from the improvements in deepsea echo-sounding. The latter can locate such buried surfaces as, for example, have been found by the Shell Oil Co. in shallow water at depths of $0-40 \mathrm{~m}$. below the bottom. Prof. Kuenen directed attention to the necessity for international co-operation in the work of exploration of the bed of the deep sea on account of the high cost, and welcomed the existence of the International Joint Commission on Oceanography which has been formed under the auspices of the International Council of Scientific Unions. The Commission is organizing a new journal of research on the deep-sea floor (to be published by the Pergamon Press, Ltd.), and Mr. C. D. Ovey, the secretary of the Commission, is one of the editors.

With reference to the theoretical aspect of sedimentation, Prof. Kuenen directed attention to the large discrepancy which has arisen between the estimates by Twenhofel and others of the total sediment thickness and the measured values obtained by seismic methods. These indicate that, instead of an overall oceanic sediment thickness of $2-3 \mathrm{~km}$., as was previously supposed, there is, in fact, much less. As a particular example, there is the $\frac{1}{2} \mathrm{~km}$. of sediments measured by Raitt in the Pacific. Low values such as these are difficult to reconcile with the accepted values of the sedimentation-rate and the estimated age of the oceans.

Prof. Kuenen next discussed the transport of sediments in the deep sea by turbidity currents. These currents - at one time known as density currents-have not been observed in the occans, but have been observed in the laboratory and in lakes. It is believed that they can be of sufficient velocity to transport the deep-sea sands, and are characterized by the graded bedding they produce and by the interstratification of decp-sea and shallow-water sedimonts in such regions as the mouths of submarine canyons. 'The distinction between turbidity currents and slumping or sliding lies in the ability of an individual particle to move freely in the former, whereas in the latter the material moves in bulk. Turbidity currents are sufficiently mobile for their momentum to carry them far beyond the slope, but slumps, on the other hand, stop at the point where the slope becomes small. Evidence for the existence of turbidity currents is not confined to the oceans but can be found in some continental rocks. For example, the graded bedding, and the interstratification of lutite in the ripple- and flow-marked graywackes of the Ventura Basin in California and elsewhere, can be attributed to this mechanism.

The turbidity currents can be of vast size and can extend to the middle of the ocean basins, but Prof. Kuenen found it difficult to believe that the cablebreaks on the continental slope and in the deep water off the Grand Banks following an earthquake in 1929 could have been caused by them. Ewing and Heezen collated the times at which the breaks occurred and concluded that, on the upper parts of the slope, velocities of the turbidity current had reached 55 knots. Later in the discussion other speakers showed doubts of this explanation of those breaks in the cable, but Prof. M. Ewing expressed confidence that these intuitive criticisms would prove incorrect. Prof. Ewing also mentioned that turbidity currents are not only confined to the regions of steep slope but are also found to exist on slopes as low as 1 in 500 , and samples of undisturbed sedimentation can be obtained most satisfactorily on submarine hills of, for example, three thousand feet in height and five miles across. Prof. Kuenen later in the discussion noted that the turbidity currents are unable to cause erosion since they are in general overloaded, although they tend to be channelled down existing canyons. There is, he believed, no single origin from the submarine canyons, and they cannot all have been formed by subaerial erosion.

Prof. F. P. Shepard gave further evidence for the existence of turbidity currents from submarine canyons along the Californian coast. The Scripps Institute has particularly good opportunities for studying these canyons in shallow water, for at La Jolla there is one within five minutes sailing from the laboratory. Sediments are deposited in these canyons, and about every eight months the amount becomes unstable and disappears seawards. It is probable that small earthquakes can initiate this process. The material is undoubtedly transported to the deep water since, for example, foraminiferal material of shallow-water origin exists at the mouth. 
Straightforward slumping cannot account for the transport, since the material is not uniformly layered in the area of deposition, and turbidity currents are the only explanation. Prof. Shepard agreed that these currents, while of primary importance in keeping the canyons clear, cannot account for their origin since their powers of erosion are inadequate.

Dr. J. D. H. Wiseman spoke of methods by which the climatic changes of the past can be detected in undisturbed deep ocean sediments. The first method is that of determining the total quantity of planktonic foraminifera in any level of the core by measurement of the percentage of carbon dioxide. These foraminifera act as temperature indicators rather than as indicators of the food supply, as is shown by their absence from antarctic waters, and consequently the quantity of carbon dioxide deposited depends directly on the temperature. Another method of determining the temperature depends upon the proportions of warm-, temperate- and cold-water forms of foraminifera found at any level in a deep-sea core, and a third method is the measurement of the proportion of the oxygen-18 isotope. This last method, which has been developed by Prof. H. C. Urey in Chicago, has been checked by investigations of Recent sediments. Dr. Wiseman showed there is agreement between the oxygen-18 and the carbon dioxide maxima down the length of a core. The rate of sedimentation of a core can be obtained by assuming that the rate of sedimentation of iron or titanium is constant and that, as would be expected on this hypothesis, there is a reciprocal relationship between the ferric oxide content and the carbon dioxide content.

Mr. B. C. Browne described the gravity results obtained by himself and those obtained by Prof. Vening Meinesz in the eastern Atlantic and in the English Channel. The scatter in the regional isostatic gravity anomalies is considerably greater in the deep water than in the shallow, the mean value for the Atlantic being $+11 \pm 19 \mathrm{mgal}$. in comparison with $+7 \pm 10$ mgal. in the Channel. This increase in variation in the ocean can probably be associated with changes in the sedimentary thickness such as have been found by seismic refraction shooting. Mr. Browne considered that the rugged topography found in some areas is caused by the basement rocks protruding through pools of sediment, and he urged that there should be a combination of seismic and gravity observations to determine the extent of the association between the anomaly variations and the sediment thickness.

Dr. G. P. Woollard and Dr. J. L. Worzel agreed that many of the gravity anomalies at sea can be accounted for by the variations in sediment thickness and gave as known examples the sediments which accumulate in the depressions caused by elastic bending of the crust around oceanic volcanoes, the sedimentary layers of the continental shelf, and the great thickness of sediments found in the Puerto Rico Trench. Prof. Ewing later reported that, owing to the great magnitude of this thickness, attempts at measurement have three times failed. It may be deduced, however, that it is at least $9 \mathrm{~km}$., which is enough to satisfy the gravity field, and for this reason it suppears that there is no deep root of lighter rock such as is required by the Vening Meinesz theory of the formation of geosynclines. Dr. Woollard said that the association between sediment thickness and gravity anomaly does not always exist on the con- tinents, and gave an example of a trough filled with sediments denser than the surrounding rocks, which nevertheless possesses a large negative free-air gravity anomaly.

Dr. J. L. Worzel described briefly the results obtained from six hundred gravity stations in the Atlantic, and explained that the common belief that the average free-air anomaly for the oceans is slightly positive is incorrect. If those stations at which the water depth is less than $3,000 \mathrm{~m}$. and greater than $6,500 \mathrm{~m}$. are rejected, the average free-air anomaly is $-3.2 \mathrm{mgal}$. The number of stations with a negative free-air anomaly was 258 and the number with a positive anomaly 195.

Prof. W. B. R. King described pebbles which have been obtained in cores in the eastern Atlantic in about the latitude of $50^{\circ} \mathrm{N}$. These pebbles include several of basalt with the corners showing glacial scratches, some limestone pebbles with trilobite shell fragments, some coarse sandstones and mica schists. These, and the clay in which they were embedded, are all of glacial origin and indicate the importance of ice as a method of transportation of deep-sea sediments. How far this method extends to the south in the Atlantic is not known.

Dr. G. M. Lees objected to the prevalent concept of the oceans as static units and referred to the downwarping which has been known to occur and would sink the continental surface to oceanic depths. $\mathrm{He}$ said that he has no confidence in the deductions from the measurement of gravity at sea which lead to the belief in fundamental differences between oceans and continents, and, as an example of the uncertainty of interpretation of gravity results, he quoted measurements from north-west Africa where there is a discrepancy of $20,000 \mathrm{ft}$. between what is supposed to exist from the gravity results and what is found in seismic prospecting. The conception of the permanence of the oceans is so firmly thrust upon the geologists that they have arranged their interpretation to fit and have rejected any hypothesis which allows the extension of geological structures into the deep sea. Later in the discussion this last point was again raised, and it was apparent that geophysicists generally agree that the earth movements producing the continental surface features can extend without break into the oceans; an example of this is the continuation of the San Andreas fault for two thousand miles into the Pacific.

The session on the deep structure of the Atlantic was opened by Prof. M. Ewing, who outlined the areas investigated by himself and his colleagues by coring and seismic refraction shooting. These areas include the continental margin of the western Atlantic, the Caribbean area and the deep North Atlantic. All the deep stations have shown the same general structure for the earth's crust; it consists of about $5 \mathrm{~km}$. of water overlying $\frac{1}{2} 1 \mathrm{~km}$. of unconsolidated sediments, and below this there are $4-5 \mathrm{~km}$. of crystalline rocks which are probably basaltic. This interpretation of material is based on the known compressional wave velocities and on the existence of olivine basalt on the mid-Atlantic ridge and islands. At the base of the basaltic layer is the Mohorovicic discontinuity, and below this the earth's mantle extends to great depths and is probably of the nature of peridotite. The work in the Caribbean indicates that, contrary to earlier beliefs, this sea is by nature representative of the deep sea and not of a sunken continent. 
Sections across the continental shelf and slope show that the Mohorovičić discontinuity slopes upwards from about 200 miles inside the coast-line, where it lies at a depth of $30-40 \mathrm{~km}$., to about 100 miles out to sea where, as under the deep ocean, it lies at a depth of $10-12 \mathrm{~km}$.

The configurations of the layers lying above the Mohorovičić discontinuity are similar on all sections across the continental shelf and slope, although there are changes in the horizontal scale. They show the continental basement rock sloping seawards with wedge-shaped sedimentary layers lying on it.

Prof. Ewing next discussed the dispersion of surface waves in the sea bed produced in earthquakes. The information agrees with the theoretically derived dispersion for a layer of water overlying the rock and indicates a similarity of structure for the beds of the Atlantic and Pacific Oceans. In spite of the sediment thickness in the Pacific being half that of the Atlantic, this cannot be observed from the dispersion, and it is apparent that for these surface waves the sedimentary layer acts as water.

Dr. M. N. Hill showed the results he and Mr. A. S. Laughton have obtained with seismic refraction shooting in the eastern Atlantic during 1952. These, while small in number compared with those obtained by Prof. M. Ewing, confirm that the Mohorovičic discontinuity lies at a depth of about $11 \mathrm{~km}$. below sea-level. Above this level the velocities are such as would be expected for basaltic rocks, and there is no evidence for the existence of any lower-velocity rocks between this layer and the base of the unconsolidated sediments. The sediments are variable in thickness; in some areas of rugged-bottom topography there appears to be none, and in other areas there is as much as $2.6 \mathrm{~km}$. The average thickness is about $1 \mathrm{~km}$. This thickness is greater than that found by Ewing in the western Atlantic, but the difference can, in part, be attributed to different assumptions conccrning the velocity of compressional waves in the sedimentary layer.

A section from the central Jinglish Channel to the deep water of the Atlantic indicates that there is a slope of the basement rocks below the semi-consolidated sediments which is more gentle than that found by Bullard and Gaskell in a line farther to the north, and it suggests that the latter happens to coincide with an extension of the structure forming the south coast of Devon and Cornwall out towards the edge of the shelf. It is possible that this structural feature extends down the continental slope, since in this region the topography of the slope is exceptionally rough.

Dr. T. F. Gaskell described the three types of crustal structure which he and Mr. J. C. Swallow have obtained by refraction shooting in the Pacific Ocean during the recent world cruise of H.M.S. Challenger. It appeared that these three types are also to be found in the Atlantic. The first type is typical of the deep ocean and consists of about $\frac{1}{2} \mathrm{~km}$. of sediments lying on a layer in which the velocity corresponds to, although it is slightly lower than, the basaltic layers referred to by Ewing and Hill. The second type is similar to that of the deep ocean except that interposed between the sediments and the basement rock lies a layer in which the velocity is such as would be expected for volcanic material. 'This interpretation is supported by the existence of volcanic islands and sea mounts in those regions where this succossion is found. The volcanic cores themselves are such that the velocity of compressional waves is similar to the basement rock. The third type, which is typified by stations on the landward side of the andesite line, shows basement velocities less than those in the other types and similar to those in the continental surface layers.

The Atlantic results of H.M.S. Challenger were mostly in the Bermuda region, and these show the second type of structure. The sea depth is about $5 \mathrm{~km}$., and the unconsolidated sediment depth $1-1 \mathrm{~km}$. Below the sediments there are lavas $1 \frac{1}{2}-2 \frac{1}{2} \mathrm{~km}$. in thickness lying on the basement rock. There is only one result from the Atlantic which belongs to the deep ocean type.

Prof. J. P. Rothé described the distribution of recent earthquake epicentres in the Atlantic and Indian Oceans and the Mediterranean Sea. The line of activity extended from the Red Sea to the Carlsberg Ridge and thence to the south of the Cape of Good Hope, joining with the mid-Atlantic ridge which passes northwards through Tristan da Cunha, St. Paul's Rocks, the Azores and thence to Iceland. The Mediterranean line of earthquake activity extended westwards as far as the mid-Atlantic ridge. Within the area roughly bounded by these lines of activity there are continental rocks, and outside there exists the typical oceanic structure. Prof. Rothé suggested that perhaps there is not the clear-cut distinction between the velocities of compressional waves in the continental type of surface-rocks and those in the basaltic layer. In support of this, he quoted an example on land where there is an obvious and typical continental surface and yet giving high velocities which Ewing associated with basaltic rocks. In spite of the evidence from seismic experiments at sea, it is therefore still possible that the sialic rocks form the sea bed below the sediments within the area bounded by the earthquake belts. This hypothesis is supported by the velocities of surface waves from earthquakes which traverse this area.

Prof. H. H. Hess stated the importance of obtaining pieces of rock from below the Mohorovičić discontinuity and believed it to be not impossible that these would be different if obtained from under the continents rather than from below the oceans. Peridotitic bombs from oceanic volcanoes probably represent the material of the mantle, although it is possible that they are aggregations from basaltic rocks. It is also probable that the periodotites obtained from St. Paul's Rocks are representative of the layers below the Mohoroviěić discontinuity.

Prof. Hess discussed the problem of guyots. He explained that, contrary to previous suppositions, their top surfaces were all of later origin than preCambrian, and these surfaces must have sunk many thousands of feet below sea-level in post-Palæozoic times. This is demonstrated by the existence of Cretaceous and Eocene fossils in the surface layers. $\mathrm{He}$ believed the Pacific guyots, which lie on lines, represent the upward edge of convection cells in the earth's mantle and that the island arcs represent the downward edge.

Dr. E. C. Bullard described the significance of the measurements of heat flow which are being made at sea. On land, measurements have been carried out for many years in mines and boreholes and have demonstrated that, within a factor of 2 , the value of the heat flow is $10^{-6} \mathrm{cal}$. $\mathrm{cm} .^{-2}$ sec.- ${ }^{-1}$. This heat flow is commonly supposed to be accounted for by the radioactivity of the continental surface rocks. Hence, it was deduced that the heat flow under the oceans would be less and that this differential heating 
between the oceans and continents could account for convection currents in the mantle and thereby many of the earth's structural features. Measurements by Maxwell and Revelle in the Pacific, and by Bullard in the eastern Atlantic, have shown that these conclusions are incorrect, the heat flow for the Pacific being roughly equal to the continental value and that for the Atlantic being slightly less and about 0.7 times the continental value; the expected heat flow, on the old hypothesis, was about 0.25 times the continental value. Explanation of this value for the heat flow is difficult, but might be accounted for by the total quantity of radioactivity in any vertical column being independent of the location of that column, in the same way as there is an equality of mass between columns.

In reply to a query by Dr. Lees concerning the heat flow from the oceans and continents being approximately the same, Dr. Bullard expressed the firm belief that this does not indicate that continents could have existed where now there are oceans, since the measured differences in structure are too great. There is, however, the irreversible possibility of continents extending into regions where there are now oceans.

M. N. HILI

\section{HATHERLY BIOLOGICAL LABORATORIES, UNIVERSITY COLLEGE, EXETER}

\section{By Prof. JOHN CALDWELL}

$\mathrm{O}^{\mathrm{s}}$ N April 23 the Hatherly Biological Laboratories of University College, Exeter, were formally opened by Sir Edward Salisbury, director of the Royal Botanic Gardens, Kew, in the presence of a gathering representative of the universities and learned societies, as well as of local and national bodies. In his address on the "Place of Biology in the University Curriculum", Sir Edward dealt with the value of the discipline of biology in a liberal education and the part that universities can play in developing a broader and more general approach to the whole subject of biology and its implications, deploring the narrow specialization which tends to isolate the biologist, and not only biologists, from the sympathy and understanding of the community. The chair was taken in the absence of the president, the Most Hon. the Marquess of Salisbury, by the deputy president, Mr. B. G. Lampard-Vachell. The thanks of the company to Sir Edward Salisbury was expressed by the principal of the College, Sir Thomas Taylor. Thereafter, before the company moved off to inspect the laboratories and the demonstrations set out in them, a brief account of the building was given by Prof. J. Caldwell, director of the laboratories. Plans were prepared for the laboratories after the College received a bequest from Mrs. Ellen Heath, of Exeter, towards the erection of a building to be associated with the name of Hatherly. The additional money was obtained through the generosity of the University Grants Committee, and the foundation stone was laid by the president of the College on July 28, 1948 (see Nature, 162, 505 ; 1948).

The laboratories, which were built to the design of Mr. E: Vincent Harris, consist of a central block with entrance hall and private rooms for members of staff and two wings facing south-east. From this there project to the west five bays, each two stories high, with the main laboratories in them. The advantage of this arrangement is that the northfacing sides of the laboratories are almost completely of glass, plate-glass sheets $11 \mathrm{ft}$. by $7 \mathrm{ft}$. in the lower floor and $7 \mathrm{ft}$. square on the upper. These ensure that there is excellent natural light in the laboratories and the orientation of the laboratories shields these windows from direct sunlight.

Three Departments are housed in the buildingBotany, Geology and Zoology. The first has two large junior laboratories each approximately $60 \mathrm{ft}$. by $30 \mathrm{ft}$., and one advanced laboratory $60 \mathrm{ft}$. by $25 \mathrm{ft}$. ; the two former have preparation and store rooms attached. The mycology laboratory, with an annexe as a sterilizing room, is $30 \mathrm{ft}$. by $25 \mathrm{ft}$., as is the lecture room above it and a fifth laboratory and reading room above that. These are in the wing to the front of the building on the south side. There are, in addition, private laboratories for the members of staff, an office and three research laboratories roughly $20 \mathrm{ft}$. square. The Department of Zoology has its laboratories in the third and fourth bays. There are two laboratories, one on the ground floor and one on the upper floor, and a series of research

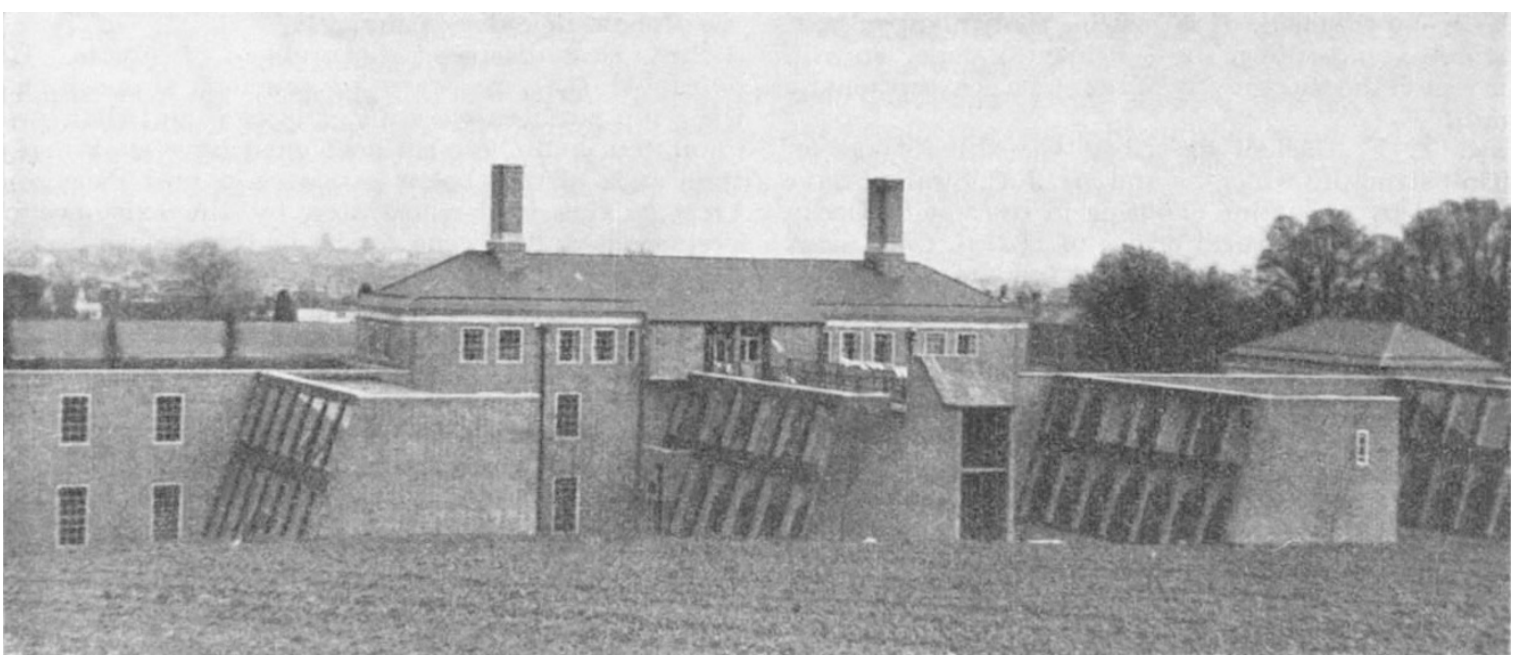

Hatherly Biological Laboratories. Main laboratories with north lights 